\title{
FAKTOR-FAKTOR YANG MEMPENGARUHI KUALITAS AUDIT PADA PERUSAHAAN MANUFAKTUR
}

\author{
FLORIAN WULANDARI HADI \\ IRWANTO HANDOJO
}

\author{
STIE Trisakti \\ wulandariflorian@gmail.com \\ irwanto@stietrisakti.ac.id
}

\begin{abstract}
The objective of this research is to obtain empirical evidence of auditor size, leverage, company growth, company size, institutional ownership, managerial ownership and company agesas independent variables to audit quality as dependent variable in Indonesian manufacturing companies.The research period is three years from 2012-2014 and population in this research is all listed companies in Indonesian Stock Exchange. Samples are obtained through purposive sampling method, which only 65 of listed manufacturing companies in Indonesian manufacturing companies meet the sampling criteria, resulting 195 data. Multiple linear regressions and hypothesis testing are used as the data analysis method in this research. The result of this research shows that leverage statistically have effect on the audit quality. While auditor size, company growth, company size, institutional ownership, managerial ownership and company ages have no effect on audit quality.
\end{abstract}

Keywords: audit quality, auditor size, leverage, company growth, company size, institutional ownership, managerial ownership, company ages

\begin{abstract}
Abstrak: Tujuan penelitian adalah untuk mendapatkan bukti empiris mengenai faktor-faktor yang mempengaruhi ukuran KAP, leverage, pertumbuhan perusahan, ukuran perusahaan, kepemilikan institusional, kepemilikan manajerial dan umur perusahaan sebagai variabel independen terhadap kualitas audit sebagai variabel dependen pada perusahaan manufaktur di Indonesia.Periode penelitian ini adalah 3 tahun dari 2012-2014 dan populasi penelitian ini adalah seluruh perusahaan yang terdaftar di Bursa Efek Indonesia dan perusahaan yang memenuhi kriteria sebanyak 65 perusahaan manufaktur yang terdaftar pada Bursa Efek Indonesia, 195 data. Metode penelitian dalam penelitian ini adalah regresi berganda dan uji hipotesis. Hasil dalam penelitian ini adalah leverage memiliki pengaruh terhadap kualitas audit. Sedangkan ukuran KAP, ukuran perusahaan, pertumbuhan perusahaan, kepemilikan institusional, kepemilikan manajerial dan umur perusahaan tidak memiliki pengaruh terhadap kualitas audit.
\end{abstract}

Kata Kunci: kualitas audit, ukuran kap, leverage, pertumbuhan perusahaan, ukuran perusahaan, kepemilikan institusional, kepemilikan manajerial, umur perusahaan 


\section{PENDAHULUAN}

Perkembangan perekonomian sudah berkembang sangat pesat. $\mathrm{Hal}$ ini memungkinkan para investor untuk berinvestasi dan membuat pelaku bisnis meningkatkan kinerja perusahaan untuk mempertahankan perusahaan dalam persaingan usaha yang terjadi. Investor yang ingin melakukan investasi tentunya akan melihat laporan keuangan yang sudah diaudit karena laporan tersebut mencerminkan kualitas yang ada dalam suatu perusahaan. Audit adalah mengumpulkan dan evaluasi bukti tentang informasi untuk menentukan dan melaporkan tingkat korespondensi antara informasi dan kriteria yang telah ditetapkan (Arens et al. 2012, 24). Pimpinan perusahaan memerlukan jasa pihak ketiga agar pertanggungjawaban keuangan yang disajikan kepada pihak luar dapat dipercaya, sedangkan pihak luar perusahaan memerlukan jasa pihak ketiga untuk memperoleh keyakinan bahwa laporan keuangan yang disajikan oleh pimpinan perusahaan dapat dipercaya sebagai dasar keputusan-keputusan yang mereka ambil (Mulyadi 1992, 6).

Laporan keuangan dibuat oleh perusahaan dan digunakan sebagai informasi kepada pengguna laporan (investor) setelah laporan tersebut diaudit oleh KAP (Kantor Akuntan Publik) yang ditunjuk oleh perusahaan. Laporan yang diaudit akan meningkatkan kepercayaan dari para pengguna laporan keuangan. Hal ini mengakibatkan permintaan akan laporan keuangan yang meningkat, sehingga terjadi peningkatan persaingan bisnis pelayanan jasa akuntan publik. Kualitas audit menjadi harapan dari pengguna laporan keuangan terutama publik atau pemegang saham yang menaruh harapan tinggi bahwa laporan keuangan yang telah diaudit oleh KAP tentunya merupakan laporan keuangan yang bebas dari salah saji material, baik yang disebabkan oleh kekeliruan atau kecurangan. Hasil kualitas audit digunakan untuk meningkatkan kredibilitas laporan keuangan pengguna informasi akuntansi sehingga dapat mengurangi resiko informasi yang tidak dipercaya dalam laporan keuangan bagi pengguna keuangan khususnya investor (Mgbame et al. 2012).

Kualitas audit menjadi perhatian publik, setelah terjadinya kasus-kasus atau skandalskandal keuangan yang merugikan banyak pihak, baik kasus di luar maupun di dalam negeri. Hal ini di mulai dari krisis buble economy atau dikenal dengan krisis perusahaanperusahaan dotcom dan perusahaan berbasis teknologi lainnya ada di Amerika Utara dan Uni Eropa. Krisis ini mengakibatkan runtuhnya raksasa energi Enron dan hilangnya kepercayaan publik terhadap salah satu kantor akuntan publik besar yaitu Arthur Andersen (Purba 1999, 1). Enron dan KAP Andersen dituduh telah melakukan kriminal dalam bentuk penghancuran dokumen yang berkaitan dengan investigasi atas kebangkrutan Enron karena KAP Enron memiliki kebijakan pemusnahan dokumen yang tidak menjadi bagian dari kertas kerja audit formal. Enron telah melanggar etika dalam bisnis dengan melakukan manipulasi guna menarik investor. Sedangkan Arthur Endersen bertindak sebagai auditor telah melanggar etika profesinya sebagai seorang akuntan karena telah melakukan kerjasama dalam memanipulasi laporan keuangan Enron sehingga Arthur Andersen tidak bersikap independen sebagai seorang akuntan. Dari kasus tersebut banyak pemegang saham (investor) yang mengalami kerugian dan menjadi meragukan integritas keseluruhan sistem kepemilikan publik dan akuntanbilitas di Amerika Serikat. Kasus Enron menunjukkan bahwa keinginan direksi untuk memperoleh insentif berupa bonus telah mendorong mereka untuk melakukan manipulasi laporan keuangan yang mengakibatkan pailitnya perusahaan tersebut (Purba 2009, 44).

Penelitian ini merupakan pengembangan dari penelitian Siregar et al. (2012) yang mengungkapkan faktor-faktor yang mempengaruhi kualitas audit di Indonesia. Peneliti 
menggunakan variabel ukuran KAP, leverage, pertumbuhan perusahaan, dan ukuran perusahaan sebagai variabel independen dan kualitas audit sebagai variabel dependen dengan mengacu pada Siregar et al. (2012). Peneliti menambah empat variabel yaitu kepemilikan institusional, kepemilikan manajerial dan umur perusahaan. Tujuan penelitian ini adalah untuk mendapatkan bukti empiris pengaruh ukuran KAP, leverage, pertumbuhan perusahaan, ukuran perusahaan, kepemilikan institusional, kepemilikan manajerial dan umur perusahaan terhadap kualitas audit.

\section{Teori Keagenan}

Dalam penelitian ini, mengunakan teori keagenan. Menurut Jensen dan Meckling (1976) organisasi merupakan jaringan kontraktual antara prinsipal dan agen. Prinsipal adalah pemilik atau pemegang saham sedangkan agen merupakan manajer perusahaan. Pemisahan antara kepemilikan dengan pengelolaan perusahaan akan menimbulkan masalah keagenan karena para pemegang saham dalam jumlah banyak dan masing-masing hanya memiliki sedikit saham, sehingga pengendalian oleh pemilik cenderung lemah dan pemegang saham sulit memastikan para manajer bertindak untuk kepentingan para pemegang saham. Konflik kepentingan tidak terlepas dari kecenderungan prinsipal untuk mencari keuntungan sendiri dan mengorbankan kepentingan pihak lain. Dalam teori keagenan, auditor sebagai pihak ketiga membantu memahami konflik kepentingan yang muncul antara prinsipal dan agen.

\section{Ukuran KAP dan Kualitas Audit}

Ukuran KAP menunjukkan kemampuan auditor untuk bersikap independen dan melaksanakan audit secara profesional karena KAP menjadi kurang bergantung secara ekonomi kepada klien. DeAngelo (1981) menunjukkan KAP besar (Big Four) akan melakukan audit dengan lebih berkualitas dibandingkan dengan
KAP kecil (Non Big Four). KAP Big Four memiliki kualitas audit yang tinggi karena memiliki karakteristik yang bisa dikaitkan dengan kualitas audit, seperti pelatihan, pengalaman dan pengakuan internasional daripada KAP Non Big Four sehingga dapat menghalangi manajemen dalam manipulasi laba. KAP besar atau yang tergolong dalam The Big Four adalah Deloitte Touche Tohmatsu, Pricewaterhouse Coopers, Ernst \& Young dan KPMG.

Menurut Amijaya dan Prastiwi (2013), perusahaan yang diaudit oleh KAP Big Four dengan keahlian dan reputasi yang dimilikinya mampu memberikan jaminan kualitas audit yang lebih baik daripada KAP Non Big Four. Penelitian Ferdiansyah (2014) menyatakan perusahaan dengan jasa audit Big Four maka akan terjadi kontrol kuat dengan laporan keuangan yang dihasilkan dan mengakibatkan kualitas audit yang tinggi. Hipotesis yang diajukan adalah:

$\mathrm{H}_{1}$ Ukuran KAP berpengaruh terhadap kualitas audit.

\section{Leverage dan Kualitas Audit}

Leverage adalah perbandingan antara total kewajiban dengan total aktiva perusahaan. Rasio ini menunjukkan besarnya aktiva yang dimiliki perusahaan yang dibiayai dengan hutang. Semakin tinggi nilai leverage maka risiko yang akan dihadapi investor akan semakin tinggi. Penelitian Defond dan Jimbalvo 1994 dalam Firtiany et al. 2015 menunjukkan semakin tinggi leverage perusahaan maka semakin rendah kualitas audit. Hal ini membuktikan bahwa tingkat hutang tinggi memiliki insentif untuk meningkatkan laba dalam memenuhi debt convenant. Hipotesis yang diajukan adalah:

$\mathrm{H}_{2}$ Leverage berpengaruh terhadap kualitas audit.

\section{Pertumbuhan Perusahaan dan Kualitas Audit \\ Menurut Aminjaya dan Prastiwi (2013) perusahaan sering kali menggunakan discrectionary accruals untuk mempertahankan eksistensi perusahaan. Penelitian Nadia (2015)}


menghasilkan pengaruh negatif terhadap discrectionary accruals, hal ini mengindikasikan kualitas audit yang dihasilkan tinggi. Jadi, semakin tinggi pertumbuhan perusahaan maka semakin tinggi kualitas audit. Hipotesis yang diajukan adalah:

$\mathrm{H}_{3}$ Pertumbuhan perusahaan berpengaruh terhadap kualitas audit.

\section{Ukuran Perusahaan dan Kualitas Audit}

Ukuran perusahaan dimasukkan karena klien yang besar mempunyai lebih banyak aset untuk dijual ketika keadaan perusahaan sedang sulit. Penelitian Choi et al. (2010) dan Almutairi et al. (2013) menunjukkan hasil yang berpengaruh signifikan dan positif antara ukuran perusahaan dengan kualitas audit, dimana semakin besar perusahaan maka kualitas audit yang dihasilkan tinggi. Hasil tersebut menunjukkan bahwa jasa audit yang disediakan oleh kantor besar memiliki kualitas lebih tinggi daripada yang disediakan kantor kecil, dalam arti kantor besar dapat menghalangi kesempatan menghalangi manajemen laba dari kantor kecil. Penelitian Lobo dan Zhou 2006 dalam Fitriany et al. 2015 menyatakan bahwa kompleksitas bisnis dan operasionalnya menyulitkan pengguna laporan keuangan untuk mendeteksi manipulasi tersebut, sehingga kemungkinan auditor mendeteksi manipulasi laba yang dilakukan oleh manajemen berkurang. Hipotesis yang diajukan adalah:

$\mathrm{H}_{4}$ Ukuran perusahaan berpengaruh terhadap kualitas audit.

\section{Kepemilikan Institusional dan Kualitas Audit}

Kepemilikan institusional merupakan saham oleh pemerintah, institusi keuangan, institusi berbadan hukum, institusi luar negeri, dana perwalian serta institusi lainnya pada akhir tahun (Ferdiansyah 2014). Menurut Wiranata dan Nurgahanti 2013, kepemilikan institusional pada umumnya memiliki proporsi kepemilikan dalam jumlah yang besar sehingga proses monitoring terhadap manajer menjadi lebih baik.
Penelitian Zureigat (2011) menemukan bahwa proporsi kepemilikan institusional yang independen maka kemungkinan terjadi kesalahan atau kecurangan kecil. Penelitian Wedar (2014) dalam Barus dan Sembiring (2012) menyatakan bahwa investor institusional memiliki waktu yang lebih banyak untuk menganalisis investasi dan memiliki kemampuan mengawasi tindakan manajemen sehingga semakin kecil peluang manajemen melakukan manipulasi angka-angka dalam laporan keuangan. Hipotesis yang diajukan adalah:

$\mathrm{H}_{5}$ Kepemilikan institusional berpengaruh terhadap kualitas audit.

\section{Kepemilikan Manajerial dan Kualitas Audit}

Semakin besar jumlah kepemilikan manajerial perusahaan semakin besar kesempatan perusahaan menghindari tindakantindakan yang merugikan perusahaan. Hal ini tentunya akan memperbesar kualitas audit yang dihasilkan. Hipotesis yang diajukan adalah:

$\mathrm{H}_{6}$ Kepemilikan manajerial berpengaruh terhadap kualitas audit.

\section{Umur Perusahaan dan Kualitas Audit}

Perusahaan yang lebih muda cenderung menyewa spesialis dari perusahaan yang memiliki umur perusahaan yang lebih tua karena sumber daya mereka terbatas dan ketidakmampuan untuk membayar auditor lebih tinggi (Almutairi et al. 2013), sehingga kualitas audit rendah. Hipotesis yang diajukan adalah:

$\mathrm{H}_{7}$ Umur perusahaan berpengaruh terhadap kualitas audit.

\section{METODE PENELITIAN}

Sampel yang digunakan dalam penelitian ini adalah perusahaan manufaktur yang secara konsisten terdaftar di Bursa Efek Indonesia (BEI) pada tahun 2012 sampai dengan 2014. Pemilihan sampel dilakukan dengan metode purposive sampling. Prosedur hasil pemilihan sampel dapat dilihat pada tabel 1 berikut ini: 
Tabel 1 Prosedur Pemilihan Sampel

\begin{tabular}{|c|c|c|c|}
\hline No & Kriteria Sampel & $\begin{array}{l}\text { Jumlah } \\
\text { Perusahaan }\end{array}$ & $\begin{array}{l}\text { Jumlah } \\
\text { Data }\end{array}$ \\
\hline 1. & $\begin{array}{l}\text { Perusahaan manufaktur yang terdaftar di Bursa Efek } \\
\text { Indonesia (BEI) berturut-turut selama periode tahun } 2012 \\
\text { sampai dengan tahun } 2014\end{array}$ & 128 & 384 \\
\hline 2. & $\begin{array}{l}\text { Perusahaan manufaktur yang tidak memiliki akhir tahun buku } \\
31 \text { Desember dalam laporan keuangannya secara konsisten } \\
\text { selama periode tahun } 2012 \text { sampai dengan tahun } 2014\end{array}$ & (4) & $(12)$ \\
\hline 3. & $\begin{array}{l}\text { Perusahaan manufaktur yang tidak menerbitkan laporan } \\
\text { keuangan dengan satuan mata uang Rupiah (Rp) }\end{array}$ & (26) & $(78)$ \\
\hline 4. & $\begin{array}{l}\text { Perusahaan manufaktur yang tidak menghasilkan } \\
\text { keuntungan berturut-turut selama periode tahun } 2012 \\
\text { sampai dengan tahun } 2014\end{array}$ & (33) & (99) \\
\hline \multicolumn{2}{|c|}{ Jumlah sampel penelitian } & 65 & 195 \\
\hline \multicolumn{2}{|r|}{ Sampel yang dieliminasi karena merupakan outlier } & & (5) \\
\hline \multicolumn{2}{|r|}{ Perusahaan manufaktur yang digunakan dalam penelitian } & & 190 \\
\hline
\end{tabular}

Kualitas audit diukur dengan menggunakan discretionary accruals dari Kansznik (1999) dalam Siregar et al. (2012). Rumus yang digunakan sebagai berikut:

$$
\begin{aligned}
& \frac{\mathrm{TACC}_{\mathrm{it}}}{\mathrm{TA}_{\mathrm{it}-1}}=\alpha 1\left(\frac{1}{\mathrm{TA}_{\mathrm{it}-1}}\right)+\alpha 2\left(\frac{\Delta \mathrm{REV}_{\mathrm{it}}-\Delta \mathrm{REC}_{\mathrm{it}}}{\mathrm{TA} A_{\mathrm{it}-1}}\right)+\alpha 3\left(\frac{\mathrm{PPE}_{\mathrm{it}}}{\mathrm{TA}_{\mathrm{i}, \mathrm{t}-1}}\right)+\alpha 4\left(\frac{\Delta C F 0_{i t}}{\mathrm{TA}_{\mathrm{it}-1}}\right)+\mathrm{l} \varepsilon_{\mathrm{it}} \mathrm{I} \\
& \mathrm{NDA}_{i t}=\alpha 1\left(\frac{1}{\mathrm{TA}_{\mathrm{it}-1}}\right)+\alpha 2\left(\frac{\Delta \mathrm{REV}_{\mathrm{it}}-\Delta \mathrm{REC}_{\mathrm{it}}}{\mathrm{TA}_{\mathrm{it}-1}}\right)+\alpha 3\left(\frac{\mathrm{PPE}_{i \mathrm{t}}}{\mathrm{TA}_{\mathrm{i}, \mathrm{t}-1}}\right)+\alpha 4\left(\frac{\Delta \mathrm{CFO}_{\mathrm{it}}}{\mathrm{TA}_{\mathrm{it}-1}}\right) \\
& \left|\mathbf{D A}_{\mathrm{it}}\right|=\frac{\mathrm{TACC}_{\mathrm{it}}}{\mathrm{TA}_{\mathrm{it}-1}}-\mathrm{NDA}_{\mathrm{it}}
\end{aligned}
$$

Keterangan:

$\mathbf{N D A}_{i t}=$ Non discretionary accruals.

TACC $_{\text {it }}=$ Total akrual perusahaan pada waktu t. (TACC it $_{\text {a }}$ net income - cash flow from operation) .

$\alpha \quad=$ Konstanta.

$\mathrm{TA}_{\mathrm{it}-1}=$ Total aset pada awal tahun $\mathrm{t}$.

$\Delta \mathrm{REV}_{\text {it }}=$ Perubahan pendapatan antara tahun $\mathrm{t}$ dan $\mathrm{t}-1$.

$\Delta \mathrm{REC}_{\text {it }}=$ Perubahan piutang antara tahun $\mathrm{t}$ dan $\mathrm{t}-1$.

$P P E_{i t} \quad=$ Aset tetap bruto tahun $\mathrm{t}$.

$\Delta \mathrm{CFO}_{\text {it }}=$ Perubahan cash flow operation antara tahun t dan t-1.

$\left|\varepsilon_{i t}\right| \quad=$ Absolut discretionary accruals. 
Ukuran KAP diberi symbol KAP. Ukuran kantor akuntan publik diukur dengan menggunakan variabel dummy. Pengukurannya (Siregar et al. 2012) adalah diberi nilai 0 jika perusahaan diaudit Non Big Four dan 1 jika diaudit Big Four (Deloitte, PwC, KPMG, dan E\&Y).

Leverage keuangan merupakan cerminan dari struktur modal perusahaan (Al-Thuneibat et al. 2011). Leverage disimbulkan dengan LEV. Pengukuran menggunakan rumus (Siregar et al. 2012):

$$
\mathrm{LEV}=\frac{\text { Total Liabilities }}{\text { Total Asset }}
$$

Pertumbuhan perusahaan diberikan simbul GROWTH. Pertumbuhan perusahaan diukur dengan membandingkan harga pasar saham perusahaan (price) dengan nilai buku (book value) dari ekuitas perusahaan sebagaimana pengukuran pertumbuhan perusahaan dalam penelitian yang dilakukan oleh Siregar et al. (2012). Rumus perhitungannya adalah sebagai berikut:

$$
\begin{aligned}
& \text { Market Price per Share of Common } \\
& \text { GROWTH = } \\
& \text { Book Value per Share of Common Stock } \\
& \text { Book Value per Share }=\frac{\text { Total Equity }}{\text { Outstanding Share }}
\end{aligned}
$$

Ukuran perusahaan merupakan ukuran atau besarnya aset yang dimiliki perusahaan. Ukuran perusahaan dilambangkan dengan SIZE. Ukuran perusahaan diukur dari logaritma alami dari total aset (Siregar et al. 2012).

\section{SIZE= Natural logarithm of total assets.}

Kepemilikan institusional merupakan saham oleh pemerintah, institusi keuangan, institusi berbadan hukum, institusi luar negeri, dana perwalian serta institusi lainnya pada akhir tahun (Ferdiansyah 2014). Pada penelitian ini, kepemilikan institusional dilambangkan dengan IO. Pengukuran kepemilikan institusional dapat diukur sebagai berikut (Zureigat 2011):

$$
\mathrm{IO}=\frac{\text { Jumlah saham pihak institusional }}{\text { Total saham beredar }}
$$

Kepemilikan manajerial adalah kepemilikan saham dari pihak manajemen (dewan direksi dan dewan komisaris) yang secara aktif ikut dalam pengambilan keputusan. Kepemilikan manajerial dilambangkan dengan MO. Pengukuran yang digunakan adalah 1 jika terdapat kepemilikan saham manajerial dan 0 jika tidak terdapat saham kepemilikan manajerial.

Umur perusahaan dalam penelitian ini menggunakan umur perusahaan dari tanggal perusahaan terdaftar di Bursa Efek Indonesia (listed date) (Al-Thuneibatet al. 2011).

\section{HASIL PENELITIAN} berikut ini: 
Tabel 2 Statistika Deskriptif

\begin{tabular}{lrrrrr}
\hline \multicolumn{1}{c}{ Variabel } & N & Minimum & Maximum & Mean & $\begin{array}{c}\text { Std. } \\
\text { Deviation }\end{array}$ \\
\hline DA & 190 & 0,00016 & 0,14269 & 0,0370509 & 0,03052637 \\
KAP & 190 & 0 & 1 & 0,45 & 0,499 \\
LEV & 190 & 0,07347 & 0,88090 & 0,4006738 & 0,17629822 \\
GROWTH & 190 & 0,07816 & 53.59006 & 3,3269928 & 6,38928806 \\
SIZE & 190 & 25,29535 & 33,09498 & 28,2521522 & 1,68601391 \\
IO & 190 & 0,00000 & 0,98241 & 0,6769791 & 0,22714460 \\
MO & 190 & 0 & 1 & 0,51 & 0,501 \\
AGE & 190 & 1 & 37 & 19,31 & 6,979 \\
\hline Sul
\end{tabular}

Sumber: Hasil Pengolahan Data SPSS IBM 21.0

Tabel 3 Ukuran KAP

\begin{tabular}{lcc}
\hline \multicolumn{1}{c}{ Information } & Frequency & Percent \\
\hline Diaudit KAP Non Big four & 104 & $54,7 \%$ \\
Diaudit KAP Big four & 86 & $45,3 \%$ \\
\hline \multicolumn{2}{l}{} \\
\hline \multicolumn{2}{l}{ Sumber: Hasil Pengolahan Data SPSS IBM 21.0 }
\end{tabular}

Tabel 4 Kepemilikan Manajerial

\begin{tabular}{lcc}
\hline \multicolumn{1}{c}{ Information } & Frequency & Percent \\
\hline Tidak terdapat kepemilikan manajerial & 93 & $48,9 \%$ \\
Terdapat kepemilikan manajerial & 97 & $51,1 \%$ \\
\hline & & $100 \%$ \\
\hline
\end{tabular}

Sumber: Hasil Pengolahan Data SPSS IBM 21.0

Tabel 5 Hasil Uji Hipotesis

\begin{tabular}{llrl}
\hline \multicolumn{1}{c}{ Variabel } & $\mathbf{B}$ & $\mathbf{t}$ & Sig. \\
\hline Constant &, 083 & 1,766 &, 079 \\
KAP &, 009 & 1,629 &, 105 \\
LEV &, 042 & 3,081 &, 002 \\
GROWTH &, 000 & 1,216 &, 226 \\
SIZE &,- 003 & $-1,564$ &, 120 \\
IO &,- 002 &,- 201 &, 841 \\
MO &, 007 & 1,581 &, 116 \\
AGE &, 000 &, 511 &, 610 \\
\hline Sumber: Hasil pengolahan data SPSS IBM 21.0
\end{tabular}


Dari tabel 5 dapat diketahui bahwa nilai signifikasi variabel ukuran KAP (KAP) sebesar 0,105 yang berarti lebih besar dari 0,05. Dari hal tersebut dapat disimpulkan bahwa $\mathrm{H}_{1}$ tidak dapat diterima, yang berarti variabel ukuran KAP (KAP) tidak berpengaruh terhadap variabel kualitas audit (DA). Hasil penelitian ini konsisten dengan penelitian yang dilakukan oleh AlThuneibat et al. (2011) namun hasil penelitian ini tidak konsisten dengan hasil penelitian yang dilakukan oleh Ferdiansyah (2014), Siregar et al. (2012), Setiawan dan Fitriany (2011) serta Nadia (2015).

Leverage (LEV) memiliki nilai signifikansi sebesar 0,002 di bawah 0,05. Dari hasil ini maka $\mathrm{H}_{2}$ diterima artinya leverage (LEV) berpengaruh terhadap discretionary accruals yang berarti berpengaruh terhadap kualitas audit. Hal ini menunjukkan bahwa tingkat leverage yang tinggi, perusahaan cenderung menggunakan discrectionary accruals dalam hal meningkatkan laba dalam untuk memenuhi debt convenant, sehingga kualitas audit yang dihasilkan semakin rendah. Hasil penelitian ini sejalan dengan penelitian Nadia (2015), Siregar et al. (2012), Siregar dan Utama (2005) serta Al-Thuneibat et al. (2011), namun hasil penelitian ini tidak sejalan dengan hasil penelitian yang dilakukan oleh Amijaya dan Prastiwi (2013).

Pertumbuhan perusahaan (GROWTH) menunjukkan nilai signifikansi sebesar 0,226 lebih besar dari 0,05. Dan dari hasil ini maka $\mathrm{H}_{3}$ tidak dapat diterima artinya pertumbuhan perusahaan (GROWTH) tidak berpengaruh terhadap kualitas audit. Hasil penelitian ini konsisten dengan penelitian Siregar dan Utama (2005), namun hasil ini tidak konsisten dengan hasil penelitian Siregar et al. (2012) dan Aminjaya dan Pratiwi (2013) serta Nadia (2015).

Ukuran perusahaan (SIZE) menunjukkan nilai signifikansi sebesar 0,120 lebih besar dari 0,05 . Dari hasil ini maka $\mathrm{H}_{4}$ tidak dapat diterima artinya ukuran perusahaan (SIZE) tidak berpengaruh terhadap kualitas audit. Hasil konsisten ini sejalan dengan penelitian Nindita dan Siregar (2012), namun hasil penelitian ini tidak sejalan dengan penelitian Almutairi et al. (2013), Ferdiansyah (2014), Zureigat (2011), Choi et al. (2010), Siregar et al.(2012), Mgbame et al. (2012), Pouraghajar et al. (2013), Nadia (2015) dan Al-Thuneibat et al. (2011).

Kepemilikan institusional

menunjukkan nilai signifikansi sebesar 0,841 lebih besar dari 0,05. Hal ini menunjukkan bahwa $\mathrm{H}_{5}$ tidak dapat diterima yang berarti variabel kepemilikan institusional (IO) tidak berpengaruh terhadap kualitas audit.Hasil ini konsisten dengan penelitian Siregar dan Utama (2005) serta Barus dan Sembiring (2012), namun hasil penelitian tersebut tidak konsisten dengan penelitian Zureigat (2011), Pouraghajar et al. (2013), Almutairi et al. (2013), dan Ferdiansyah (2014). Hasil penelitian ini konsisten dengan penelitian penelitian Barus dan Sembiring (2012), Soliman dan Elsalam (2012) serta Ferdinsyah (2014), namun hasil penelitian ini tidak konsisten dengan hasil penelitian oleh Syafruddin dan Pratama (2013) serta Pouraghajar et al. (2013) yang menunjukkan hasil berpengaruh signifikan terhadap kualitas audit.

Umur perusahaan (AGE) menunjukkan nilai signifikansi sebesar 0,610 lebih besar dari 0,05 . Hal ini menunjukkan bahwa $\mathrm{H}_{7}$ tidak dapat diterima yang berarti variabel umur perusahaan (AGE) tidak berpengaruh terhadap kualitas audit. Hasil penelitian ini sejalan dengan Brooks et al. (2012), Cahyonowati dan Putri (2013) serta Al-Thuneibat et al. (2011), namun hasil penelitian ini tidak sejalan dengan hasil penelitian yang dilakukan oleh Almutairi et al. (2013).

\section{PENUTUP}

Berdasarkan hasil penelitian dapat diperoleh kesimpulan bahwa leverage berpengaruh terhadap kualitas audit. Sedangkan ukuran KAP, pertumbuhan perusahaan, ukuran perusahaan, kepemilikan institusional, kepemilikan manajerial dan umur perusahaan tidak berpengaruh terhadap kualitas audit. 
Keterbatasan penelitian ini adalah. Periode pengamatan dalam penelitian ini hanya 3 tahun. Variabel independen yang digunakan hanya terbatas pada ukuran KAP, leverage, pertumbuhan perusahaan, ukuran perusahaan, kepemilikan institusional, kepemilikan manajerial dan umur perusahaan.

Berdasarkan keterbatasan penelitian, kontribusi untuk penelitian selanjutnya adalah memperpanjang tahun penelitian sehingga diharapkan bisa mendapatkan hasil yang lebih akurat yaitu 5 tahun periode penelitian.Penelitian selanjutnya dapat menambah variabel independen lainnya yang dapat mempengaruhi kualitas audit seperti return on asset (ROA) dan cash flow from operation (CFO). 


\section{REFERENSI:}

Adeyemi, Semiu Babatunde dan Temitope Olamide Fagbemi. 2010. Audit Quality, Corporate Governance and Firm Characteristics in Nigeria. International Journal of Business and Management, 5(5): 169-179.

Almutari, Ali R. 2013. The Impact of Institusional Ownership and Corporate Debt on Audit Quality. Journal of Economic and Administrative Sciences, 29(2): 134-152.

Al-Thuneibat, Ali Abedalqader, Ream Tawfiq Ibrahim Al Issa, Rana Ahmad Ata Baker. 2011. Do audit tenure and firm size contribute to audit quality? Empirical evidence from Jordan. Managerial Auditing Journal, 26(4), 2011: 317-334.

Amijaya, Muhammad Dody dan Anri Prastiwi. 2013. Pengaruh Kualitas Audit Terhadap Manajemen Laba. Diponegoro Journal of Accounting, 2(3): 1-13. ISSN: 2337-3806.

Anderson, David R et al. 2014. Statistics for Business and Economics. $12^{\text {th }}$ Edition. South-Western College.

Arens, A., Elder, R. \& Beasley, M. 2012. Auditing and Assurance Services. 14th Edition. Pearson Prentice-Hall, Englewood Cliffs, NJ. Pearson.

Barus, Andreani Caroline, dan Yosephine Natalia Sembiring. 2012. Faktor-Faktor Yang Mempengaruhi Motivasi Manajemen Laba Di Seputar Right Issue. Jurnal Wira Ekonomi Mikroskil, 2(1), April.

Brooks, Li, C.S, Agnes Cheng, Kenneth J. Reichelt. 2012. Audit Firm Tenure and Audit Quality: Envidence from U.S. Firms.

Cahyonowati, Nur dan Tifani Malinda Putri. 2014. Pengaruh Auditor Tenure, Ukuran Kantor Akuntan Publik, dan Ukuran Perusahaan Klien Terhdap Kualitas Audit. Diponegoro Journal of Accounting, 3(2): 1-11.

Choi, Jong-Hag, Chansong Kim, Jeong-Bon Kim, dan Yoonseok Zang. 2010. Audit Office Size, Audit Quality and Audit Pricing. Auditing: A Journal of Practice \& Theory, 29(1): 73-97.

DeAngelo, Linda Elizabeth. 1981. Audit Size and Audit Quality. Journal of Accounting and Economics, 3(3): 183-199.

Ferdiansyah, Vicky. 2014. Pengaruh Kualitas Audit, Kompensasi Bonus, Struktur Kepemilikan dan Ukuran Perusahaan Terhadap Manajemen Laba. Jurnal TEKUN, 5(2): 230-249.

Fitriany, Sidharta Utama, Dwi Martani, dan Hilda Rosietta. 2015. Pengaruh Tenure, Rotasi dan Spesialisasi Kantor Akuntan Publik (KAP) Terhadap Kualitas Audit: Perbandingan Sebelum dan Sesudah Regulasi Rotasi KAP di Indonesia. Jurnal Akuntansi dan Keuangan, 17(1): 12-27.

Pouraghajan, Abbasali, Nasser Ali Yadollahzadeh Tabari, dan MiladHaghparast. 2013. The Effect of Ownership Structure on Audit Quality: Envidence from Tehran Stock Exchange. World of Sciences Journal, 1(15): 3946.

Imata, Dea dan Rutji Satwiko. 2011. Faktor-Faktor Yang Mempengaruhi Kepemilikan Managerial. Jurnal Bisnis dan Akuntansi, 13(1): 67-80.

Jackson, Andrew B., Michael Moldrich and Peter Roebuck. 2008. Mandatory Audit firm Rotation and Audit Quality. Managerial Auditing Journal, 23(5): 420-437.

Jensen, Michael C, and William H. Meckling. 1976. Theory of the firm managerial behavior, agency costs and ownership structure. Journal of Financial Economics, Vol. 3, No. 4: 305- 360.

Mgbame, C. O., Eragbhe, E, dan Osazuwa, N. 2012. Audit Partner Tenure and Audit Quality: An Empirical Analysis. European Journal of Business and Management, 4(7): 154-159.

Mulyadi. 1992. Pemeriksaan Akuntan. Edisi empat. Yogyakarta: Bagian Penerbitan Sekolah Tinggi IImu Ekonomi YKPN.

Nadia, Nurul Fitri. 2015. Pengaruh Tenur KAP, Reputasi KAP dan Rotasi KAP Terhadap Kualitas Audit. Jurnal Akuntansi Bisnis, 13(26): 113-130.

Nindita, Chairunissa dan Sylvia Veronica Siregar. 2012. Analisis Pengaruh Ukuran Kantor Akuntan Publik Terhadap Kualitas Audit di Indonesia. Jurnal Akuntansi dan Keuangan,14(2): 91-104. 
Purba, Marisi P. 2009. Asumsi Going Concern; Suatu Tinjauan terhadap Dampak Krisis Keuangan atas Opini Audit dan Laporan Keuangan.

Sekaran, Uma dan Roger Bougie. 2013. Research Method for Business. 6th Edition.

Setiawan, Liswan W. dan Fitriany. 2011. Pengaruh Workload dan Spesialisasi Auditor Terhadap Kualitas Audit dengan Kualitas Komite Audit sebagai Variabel Pemoderasi. Jurnal Akuntansi dan Keuangan Indonesia, 8(1): 36-53.

Siregar, Sylvia Veronica N.P. dan Siddharta Utama, 2005. Pengaruh Ukuran Perusahaan dan Praktek Corporate Governance terhadap Pengelolaan Laba (Earning Management). SNA VIII Solo.

Siregar, Veronica, Fitri Amarullah, Arie Wibowo dan Viska Anggraita. 2012. Audit Tenure, Audit Rotation, and Audit Quality: The Case of Indonesia. Asian Journal of Business and Accounting, 5(1): 55-74.

Soliman, Mohamed M. dan Mohamed Abd Elsalam. 2012. Corporate Governance Practices and Audit Quality: An Empirical Study of the Listed Companies in Egypt.World Academy of Science, Engineering, and Technology, 71: 1292-1297.

Suseno, Novie Susanti. 2013. Infuence of Independence, Size of Public Accountant Office Toward Audit Quality and Its Impact on Public Accountant Office Reputation. Inernational Journal of Scientific \& Technology Research, 2(3): 123-126.

Syafruddin, Muchammad dan Bagus Pratama. 2013. Pengaruh Struktur Kepemilikan Perusahaan Terhadap Kualitas Audit. Diponegoro Journal of Accounting, 2(2): 1-13.

Wiranata, Yulius Ardy dan Yeterina Widi Nugrahanti. 2013. Pengatuh struktur kepemilikan terhadap probabilitas perusahaan manufaktur di Indonesia. Jurnal Akuntansi dan Keuangan, 15(1): 15-26.

Zureigat, Qasim Mohammad. 2011. The Effect of Ownership Structure on Audit Quality: Evidence from Jordan. International Journal of Business and Social Science, 2(10): 38-46. 